\title{
Australia lifts ban on cloning
}

Australia has ended its ban on research that involves therapeutic cloning - giving researchers there a chance to join the small number of groups engaged in the procedure worldwide.

A bill lifting the ban was passed by the Senate last month, and by the lower house on 12 December despite being opposed by both prime minister John Howard and the leader of the opposition, Kevin Rudd.

"I was losing confidence that we had the support," says an elated Alan Trounson, director of the Monash Immunology and Stem Cell Laboratories in Melbourne. "But were able to win - even against the most powerful figures."

Therapeutic cloning refers to the extraction of stem cells from embryos created by cloning, sometimes known as somatic-nuclear cell transfer. It can potentially create stem cells from patients with diseases such as Alzheimer's, multiple sclerosis or diabetes. Trounson hopes to use such stem cells to study the progression of these diseases and their possible treatment.

The bill repealed this month - the 2002 Prohibition of Human Cloning Act - banned the creation of cloned embryos for either reproduction or research. In 2004, Australia supported a US-led effort to have the United Nations ban all forms of cloning.

But now Australia becomes one of several countries, including Britain, Finland, Singapore and South Korea, that specifically permit the creation of cloned embryos for research

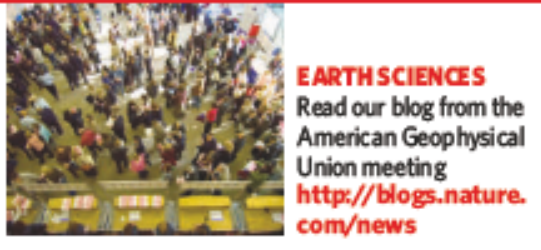

which carries a slight risk of serious side-effects (see Nature 442, $606-608 ; 2006$ ). Australia will forbid direct payments to egg donors, and its researchers will have to rely on altruistic donations or on eggs from ovaries that have been removed for medical reasons. "There is not going to be an avalanche of research in the field," says Tejia Peura, a stem-cell researcher at Sydney IVF, a fertility treatment company. She thinks that hers is one of three or four groups, at most, that will take up the research.

But the bill also opens up other avenues of related investigation. Parthenogenetic activation of eggs,

purposes under certain conditions. The United States has no law stating what work researchers may or may not do- but they cannot use federal funding for therapeutic cloning. US researchers nonetheless account for abouthalf of the groups known to be pursuing research on therapeutic cloning.

In 2005 , a committee chaired by John Lockhart, a Sydney lawyer, reviewed Australia's 2002 cloning act. Its findings, which stressed the potential value of therapeutic cloning, are reflected in the new bill.

But the same bottleneck that has limited research elsewhere in the world - the low availability of human eggs - will also slow therapeutic cloning in Australia. Eggs are needed to reprogramme donor cells to an embryonic state. Women who donate eggs must undergo the same invasive procedure as those who have in vitro fertilization (IVF), in which eggs start development without a sperm, will be allowed, for example. So will research involving the transfer of cytoplasm, the material surrounding the nucleus of an egg. The latter could lend insight into why eggs age, and, perhaps, offer hope for families with an abnormality in the cytoplasmic mitochondrial DNA that causes Leigh's disease in children. The bill will, however, prohibit the production of human embryonic stem cells by injecting human donor cells into animal eggs.

Details of how the change will be implemented, including licensing requirements for researchers, are expected early in the new year. Trounson says he cannot wait to get started, but adds that the widespread support the measure attracted has also been a huge boost for scientists' morale. "It was a great show of democracy in Australia," he says.

David Cyranoski

\section{Stem-cell techique 'contrary to public order'}

\section{MUNICH}

A German court has revoked a patent on a methodfor generating a class of human embryonic stem cells. The 5 December ruling is seen as yet another setback for stem-cell researchin a nation where it is already constrained by tight regulation.

The federal patent court in Munich heard a charge brought by Greenpeace that the patent, held by University of Bonn neurobiologist Oliver Brüstle on a way togenerate precursor nerve cells, was 'contrary to publicorder'. The environmental group argued that the derivation of the cell lines inquestion had involved the destruction of humanembryos, which breaches guidelines issued by the German Patent Office. The judge, Eva-Maria Schermer, quickly ruled in Greenpeace's favour - much to the dismay of Brüstle, who arrived in court with three bodyguards to protect him.

The ruling will become binding in a few weeks. It was made in the wake of a public call by Germany's largestresearch agency, the DFG, for a relaxation of stem-cell laws, which are stricter than those of many other European countries (see Nature 444, 253; 2006).

Brüstle says he will now appeal to the Supreme Courtin Karlsruhe, arguing that the ruling goes beyond German law, whichallows the use of human embryonic stem-cell lines created before 2002 . Justlast year, the ministry of research awarded Brüstlea grant for work with human embryonic stem cells derived before 2002. He points out that the ministry stipulates thatits grantees should attempt to patent inventions from projects thatitsupports.

But a ruling by the Supreme Court in Karlsruhe could take years. "In the meantime, it is very hard on me and my family," Brustle says, "particularly for kids whose father has been accused of doing things so bad they are considered to be against public order."

Alison Abbott 